\title{
PERCEIVED MATE AVAILABILITY INFLUENCES INTRASEXUAL COMPETITION, JEALOUSY AND MATE-GUARDING BEHAVIOR
}

\author{
S. ARNOCKY ${ }^{1, *}$, A. RIBOUT ${ }^{1}$, R.S. MIRZA ${ }^{1}$, J.M. KNACK ${ }^{2}$ \\ ${ }^{1}$ Nipissing University North Bay, Ontario, Canada \\ ${ }^{2}$ Clarkson University, Potsdam, New York
}

\begin{abstract}
Mate availability has been shown to influence intrasexual competition and mateguarding behavior across a variety of species. Nevertheless, little is known about how perceived mate scarcity affects such behavior in humans. The purpose of this study was to examine the effects of experimentally induced perceptions of mate availability upon intrasexual competition, jealousy and aggressive mate guarding behavior. Heterosexual undergraduate students $(N=124$, 60 women, 64 men) were primed with perceptions of either mate scarcity or mate abundance and subsequently completed measures of intrasexually competitive attitude, jealousy and willingness to aggress against a mate-poacher (either directly or indirectly). For both men and women, results showed that individuals who were exposed to the mate scarcity condition reported significantly more intrasexual competition, jealousy and willingness to aggress indirectly against a matepoacher compared to those exposed to the mate abundance condition. Results provide evidence of an attitudinal and behavioral shift toward sexual conflict when individuals perceive mates to be a scarce resource.
\end{abstract}

Keywords: operational sex ratio (OSR), intrasexual competition, mate guarding; indirect aggression, jealousy

\section{INTRODUCTION}

It is well understood that reproductive success can be maximized by defeating intrasexual rivals for contested mating opportunities (DARWIN 1859, 1871; GOULD 1974). Yet intrasexual competition is simultaneously risky, with the potential for status and resource loss, social exclusion, injury, or death (BENENSON 2011; DALY and WILSON 1989; FERNANDEZ-DUQUE and HUCK 2013). For these reasons, the frequency and ferocity of intrasexual competition is not indiscriminate (MAYNARD SMITH 1974). Rather, its occurrence varies according to contextual influences such as the relative scarcity of mates in the local environment, as evidenced by the population's operational sex ratio (OSR) - or the proportion of fertilizable females to sexually active males (EMLEN and ORING 1977).

When the sex ratio is skewed, members of the scarcer sex have better mating prospects (FISHER 1930) and can therefore express greater choosiness in their mate selection

\footnotetext{
*Address for correspondence: S. ARNOCKY, Nipissing University North Bay, Ontario, Canada.E-mail: stevena@nipissingu.ca
} 
(BERGLUND 1994; EMLEN and ORING 1977). For members of the abundant sex, mating opportunities are more limited given the greater proportion of same-sex competitors to potential mates (EMLEN and ORING 1977). A skewed sex ratio will typically lead to more intrasexual competition for mate acquisition and more mate-guarding behavior among members of the abundant sex. For example, COLWELL and ORING (1988) examined the effects of mate scarcity on intrasexual competition in the Wilson's phalarope, a sex-role reversed shorebird. During times in which males were scarce, for example due to clutch failures or asynchronous spring arrivals, the researchers observed that females pursued mates with greater intensity and guarded them more vigorously compared to times when males were abundant.

Hitherto, the influence of mate scarcity on intrasexual competition for mates and mate-guarding has been demonstrated in both experimental and naturalistic observations of many vertebrate species including various amphibians (LEE and PARK 2009; TEJEDO 1988), fishes (ARONSEN et al. 2013; WACKER et al. 2013), birds (COLWELL and ORING 1988), rodents (ZHANG and ZHANG 2003), and non-human primates (MITANI, GROS-LOUIS and RICHARDS 1996). A recent meta-analysis confirmed that mate scarcity relates to significant changes in intrasexual competition such as more frequent courtship displays, as well as increased aggression and mateguarding (WEIR, GRANT and HUTCHINGS 2011). Although recent research has begun to explore the influence of mate availability upon human behavior (in particular, mate selection and preferences), there remains a paucity of research on how mate availability might also influence intrasexual competition and mate-guarding behavior. To address this gap in knowledge, we experimentally manipulated individuals' perceptions of mate availability and assessed subsequent intrasexually competitive attitudes and mate-guarding intentions using attitudinal and scenariobased self-report measures.

\section{Mate availability, sexual selectivity and competition in humans}

Recent cross-sectional research has found sexual selectivity to be correlated with human sex ratios (e.g., STONE, SHACKELFORD and BUSS 2007), such that members of the scarcer sex express greater choosiness regarding the characteristics they desire in a mate. It has been established that mate preferences can fluctuate dynamically based upon contextual cues (e.g., LI et al. 2002) including one's own value as a mate (BUSS 2008). KRUGER, FitzGERALD and PETERSON (2010) found that female scarcity (relative to the number of men in large metropolitan areas in the United States) was associated with reduced marital age among women and greater variability in marital age among men. The authors suggested that when women are scarce, they have more "bargaining power" and are able to obtain commitment at earlier ages, with some men inevitably being excluded from mating opportunities altogether. In line with this argument, scarcity of women has previously been associated with increased marital stability (PEDERSEN 1991), and with women's increased interest in cues to men's commitment (BUSS 2003) and socio-economic 
status (POLLET and NETTLE 2008). Conversely, when men are scarce in a population, the proportion of men who marry young is reduced given men's increased short-term mating success and decreased incentive for commitment (KRUGER and SCHLEMMER 2009). In such circumstances women have been observed to have stronger career aspirations (perhaps in lieu of obtaining a long-term, investing mate; DURANTE et al. 2012), to wear more revealing clothing (BARBER 1999) and to engage in more casual sex (SOUTH and TRENT 1988; SCHMITT 2005; STONE, SHACKELFORD and BUSS 2007), presumably as a function of intrasexual competition. Interestingly, men's aggression and violent crime may simultaneously increase in order to procure these short-term mating opportunities (BARBER 2009).

The relationship between mate scarcity and increased selectivity has been the topic of recent experimental research as well. WATKINS and colleagues (2012) primed women with perceived sex-ratio differences using photographs. In one condition, heterosexual women viewed images depicting abundant opposite-sex individuals compared to same-sex individuals. In the second condition, participants viewed images depicting abundant same-sex individuals compared to opposite-sex individuals. Following exposure to one of these two conditions, participants rated their preference for male facial symmetry, which is considered to be a visible cue to genetic quality and health (GANGESTAD and SIMPSON 2000; JONES et al. 2001; THORNHILL and GANGESTAD 2006). Results showed that females expressed greater selectivity, as evidenced by an increased preference for facial symmetry, when men were perceived as being abundant versus scarce. Similar experimental results have been shown regarding men's mate preferences and behavior. For instance, TAYLOR (2013) found that men who endorsed traditional gender roles were more selective and assessed their own attractiveness as being higher when primed with mate abundance versus scarcity. Sexual selectivity by one sex invariably breeds intrasexual competition among members of the opposite sex who will vary in their reproductive success (BATEMAN 1948). GRISKEVICIUS et al. (2011) found that under conditions of male abundance and female scarcity, men were expected to spend more money during the courtship process. Not surprisingly, then, the researchers also found that men were willing to decrease their monetary saving and increase borrowing for immediate expenditures, suggesting that men aim to enhance the epigamic display of wealth/resources when mates are harder to come by.

In many sexually reproducing species, including humans, the effects of mate availability extend beyond mere epigamic display toward 1) direct intrasexual competition between rivals, and 2) mate-guarding behaviors after a pair-bond has been established. In the present study, we examine whether these additional indices of sexual conflict are also influenced by mate availability in humans. 


\section{Human intrasexual competition}

Similar to most sexually reproducing species, females' requisite parental investment necessitates their sexual selectivity, prompting males to compete for mating access (CAMPBELL 1995; DALY and WILSON 1988; GEARY 2000; TRIVERS 1972). Unlike most mammalian species, however, men also invest considerable time, effort and resources toward the survival and fitness of offspring (BUUNK and FISHER 2009; GEARY 2000). Monogamy and paternal investment increase sexual selectivity among men (CAMPBELL 2004; FERNANDEZ-DUQUE and HUCK 2013). In turn, women have also been shown to compete intrasexually in order to attain and guard desirable mates (e.g., ARNOCKY, SUNDERANI and VAILlANCOURT 2013; ARNOCKY et al. 2012; ARNOCKY and VAILLANCOURT 2012; BUSS and SHACKELFORD 1997; CAMPBEll 1995; ClutTON-Brock 2007; Sunderani, ARNOCKY and VaIllanCOURT 2013; VAILLANCOURT 2005). Recent evidence suggests that individuals vary in the competitive attitudes they hold toward members of the same sex (BUUNK and FISHER 2009). Moreover, both men and women have been shown to actively compete for the retention of a desirable mate through the use of aggressive behavior. For some men, physical aggression is used to guard sexual partners even at the risk of physical injury or death (WILSON and DALY 1985). For instance, men living in a Caribbean village have been shown to aggressively confront others more frequently when their partner was fecund (FLINN 1988). Men in existing pair-bonds have also been shown to experience jealousy and engage in physical aggression in response to sexual interlopers. Jealousy is considered by evolutionary psychologists to be an adaptive emotional response to a reproductive threat which might serve to motivate compensatory behavioral responses including acts of aggression (e.g., MANER et al. 2005). At the extreme end, some men will kill other men who have been discovered to have had sex with their wife or girlfriend (DALY and WILSON 1988).

More often for both men and women, mate-guarding takes the form of less physically damaging, indirect modes of aggression such as competitor derogation, social exclusion, or rumor spreading (ARNOCKY and VAILLANCOURT 2012; BJÖRKQVIST 1994; BUSS and DEDDEN 1990; BUSS and SHACKELFORD 1997; CAMPBELl 1999; VAILLANCOURT 2005). Given the need to remain alive in order to rear offspring (BJÖRKQVIST 1994; CAMPBELL 1999, 2004), the use of surreptitious, less physically damaging modalities may be particularly effective among women. Indirect aggression may be a useful strategy in competing for and retaining mates (ARNOCKY et al. 2012; ARNOCKY and VAILlANCOURT 2012; VAILlANCOURT 2005). For INSTANCE, women's derogation of other women can reduce male perceptions of the targeted woman's level of attractiveness (FISHER and COX 2009). For both males and females, the use of indirect aggression predicts having a romantic partner one year later (ARNOCKY and VAILLANCOURT 2012). Women in heterosexual romantic relationships have also been shown to experience increased jealousy and indirect aggression when they perceive their same-sex conspecifics as being 
more physically attractive than themselves (ARNOCKY et al. 2012). Taken together, it is evident that human mating competition is a multifaceted construct comprised of, but not limited to, intrasexually competitive attitudes (e.g., competitiveness toward same-sex conspecifics), emotions (e.g., jealousy) and mate-guarding behaviors (e.g., direct and indirect aggression toward a mate-poacher) experienced and expressed by both men and women (e.g., ARNOCKY et al. 2012; COX and FISHER 2008). Each of these outcomes is therefore expected to vary according to differential perceptions of mate availability.

\section{The present study}

Across many vertebrate species, skewed OSR has been shown to increase sexual competition among members of the abundant sex (WEIR, GRANT and HUTCHINGS 2011). To date, this phenomenon has not been examined experimentally with respect to many aspects of human intrasexual competition, such as attitudinal, emotional and aggressive tendencies. In the present study, participants were primed with either perceived mate scarcity or mate abundance using fictitious magazine articles. We hypothesized that participants in the mate scarcity condition would self-report significantly greater desire to compete with same-sex conspecifics (BUUNK and FISHER 2009). Moreover, we expected that upon exposure to hypothetical sexual rival, participants in the mate scarcity (versus mate abundance) condition would express more jealousy and would be more willingness to aggress against the intrasexual rival. Based upon the reviewed literature on human intrasexual competition, we did not expect sex differences in priming condition's effects on intrasexually competitive attitude, jealousy or indirect aggression. However, we did expect to find a sex difference in the perpetration of physical aggression, which men are known to engage in more frequently (ARCHER 2004; ARCHER and CôTÉ 2005).

\section{METHOD}

\section{Participants}

One hundred and twenty-four heterosexual students (64 males and 60 females) from a small Canadian University were recruited from common areas on campus $\left(M_{\text {male }}=\right.$ 22.13 years, $S D=5.36 ; M_{\text {female }}=22.38$ years, $S D=4.79$ respectively). Of these individuals, $58 \%$ of men and $42 \%$ of women were currently in a romantic relationship. Both male and female samples were comprised of primarily Caucasian participants $($ male $=95.3 \%$; female $=93.3 \%)$. Remuneration consisted of a chance to win a $\$ 50$ draw. 


\section{Materials and procedure}

\section{Priming mate scarcity versus mate abundance}

Using a set of fictitious magazine articles developed by SPIELMANN, MACDONALD, and WILSON (2009), participants were primed with the belief that potential mates were either abundant or scarce. In this task, participants were asked to read one of two articles. In the mate abundant condition, the article explained the task of finding a new romantic partner as being relatively easy, with the mating population consisting of many available mates. Conversely, in the mate scarcity condition, the article highlighted the difficulty of finding a new romantic partner, with desirable mates being a scarce resource. Previous research has shown this manipulation to be effective in inducing differential levels of optimism/pessimism in the ability to procure a mate (SPIELMANN et al. 2009).

\section{Intrasexually competitive attitude}

Participants next completed the Intrasexual Competition Scale (ICS) which assessed the degree to which an individual is motivated to compete with members of the same sex (BUUNK and FISHER 2009). Previous research has found the ICS to be a valid and reliable tool for measuring attitude toward intrasexual competition (BUUNK and FISHER 2009). The scale consisted of 12 items rated on a seven-point Likert-type scale ranging from 1 = "not at all applicable" to 7 = "completely applicable." Example items include: "I would not hire a competent man/woman as a colleague," "I can't stand it when I meet another woman who is more attractive than I am," "When I'm at a party, I enjoy it when men/women pay more attention to me than other men/women," "I wouldn't hire a very ambitious man/woman as a colleague" and "I always want to beat other men/women." In the present study, the measure showed good internal consistency in both males $(\alpha=.85)$ and females $(\alpha=.87)$.

\section{Jealousy toward a mate-poacher}

Jealousy and emotional reactivity toward a sexual competitor was examined using a paradigm developed by DIJKSTRA and BUUNK (1998) in which participants were presented with the following scenario:

"You are at a party with your girlfriend and you are talking with some of your friends. You notice your girlfriend across the room talking to a man you do not know. You can see from his face that he is very interested in your girlfriend. $\mathrm{He}$ is listening closely to what she is saying and you notice that he casually touches her hand. You notice that he is flirting with her. After a minute, your girlfriend also begins to act flirtatiously. You can tell from the way she is look- 
ing at him that she likes him a great deal. They seem completely absorbed in each other."

Immediately following this narrative, participants were presented with a color photo of the attractive intrasexual rival, along with a narrative describing the competitor's desirable personality and social qualities. In order to develop this stimuli, we asked a separate sample of 20 males and 20 females to rate the attractiveness of photographs of opposite-sex models' faces using a scale anchored at $1=$ "not at all attractive" and 5 = "very attractive." Photos were obtained from a royalty-free online database. The top-rated male and female faces were then selected for use as our attractive intrasexual rival stimuli for the present study $\left(M_{\text {male face }}=3.71, S D=\right.$ $.96, M_{\text {female face }}=3.81, S D=1.93$ ).

Following the methodology of DIJKSTRA and BUUNK (1998), participants read a description of personality traits the rival possessed that have been shown to appeal to the opposite sex (DJIKSTRA and BUUNK 1998, 2002, POLLET and NETTLE 2008). Male and female participants read a description of their sexual competitor as being high in status, highly involved in social activities, influential, and as a good judge of character (DJIKSTRA and BUUNK 1998). These factors have been associated with cues individual's look for in high-quality mates and have been associated with high mate-value characteristics (DJIKSTRA and BUUNK 1998, 2002; POLLET and NETTLE 2008).

After exposure to this scenario, participants responded to a multiple adjective measure of jealousy (see DJIKSTRA and BUUNK 1998 for review), which includes items asking how suspicious, distrustful, jealous, rejected, hurt, anxious, threatened, sad and upset they felt using a 5-point Likert-type scale anchored at $1=$ "not at all" to 5 = "very strong" (DIJKSTRA and BUUNK 1998). Multiple adjective measures of jealousy are meant to curtail an under-reporting of jealousy existent among other measures (DJIKSTRA and BUUNK 1998). In the present study, the measure was internally consistent for both males and females ( $\alpha=.91$ and $\alpha=.90$ respectively).

\section{Direct and indirect aggression toward a mate-poacher}

Participants were then asked how they would react to this person at the party. There were four questions pertaining to direct aggression including: "I would hit him/her for flirting with my partner," "I would challenge him/her to a fight," "I would shove him/her," and "I would threaten him/her to stay away from my girlfriend/boyfriend." Questions pertaining to methods of indirect aggression included: "I would tell my friends what an asshole/bitch he/she is," "I would make a joke to my friends about how ugly he/she is," "I would have my friend (the host of the party) ask him/her to leave" and "I would call him/her a derogatory name to his/her face." Participants responded using a five point Likert-type scale ranging from $1=$ "not at all" to 5 = "very strong." In the present study, the internal consistency for this 
measure for males and females were $\alpha=.89$ and $\alpha=.86$ respectively. Principle component analysis using a varimax rotation showed that the four direct aggression items loaded on a unique dimension with factor loadings ranging between .37 and .87 and contributed $43 \%$ toward explained variance. The direct aggression subscale was internally consistent among men and women, $\alpha=.89$ and $\alpha=.78$ respectively. The four indirect aggression items loaded on a separate factor with loadings ranging between .68 and .91 and contributed 30\% toward explained variance. The indirect aggression subscale was internally consistent among men and women, $\alpha=.86$ and $\alpha=.87$ respectively.

\section{Analyses}

A two-way between-subjects multivariate analysis of variance (MANOVA) was conducted to determine the effects of the mate availability priming conditions (scarcity versus abundance) upon four dependent variables (intrasexual competitive attitude, jealousy toward a rival, willingness to aggress indirectly and to aggress physically against an intrasexual rival). A statistically insignificant Box's M test indicated homogeneity of the covariance matrices across conditions $(p=.11)$. Additionally, Bartlett's test of sphericity indicated sufficient correlation between the dependent variables $\left(\chi^{2}=81.36, p<.001\right)$. The Bonferroni-corrected $p$-value of .012 was used to measure the significance of univariate relationships. Bivariate correlations are presented in Table 1 and descriptive statistics are presented in Table 2.

Table 1. Bivariate correlations. Male data are presented below the diagonal, female data are presented above the diagonal

\begin{tabular}{llllll}
\hline & 1 & 2 & 3 & 4 & 5 \\
\hline 1. Condition & 1 & $.50 * *$ & $.37 * *$ & $.45^{* *}$ & .13 \\
2. Intrasexual competition & $.37 * *$ & 1 & $.43 * *$ & $.52 * *$ & .17 \\
3. Jealousy & $.40^{* *}$ & $.58^{* *}$ & 1 & $.67 * *$ & .25 \\
4. Indirect aggression & $.42 * *$ & $.44 * *$ & $.63 * *$ & 1 & $.46^{* *}$ \\
5. Direct aggression & $.26^{*}$ & $.25^{*}$ & $.48^{* *}$ & $.62 * *$ & 1 \\
\hline
\end{tabular}

Note: $* p<.05$ (two-tailed). $* * p<.01$ (two-tailed).

Table 2. Descriptive statistics by sex

\begin{tabular}{lcccccccc}
\hline & $N$ & & $M$ & & \multicolumn{2}{c}{$S D$} & \multicolumn{3}{c}{ Range } \\
& Male & Female & Male & Female & Male & Female & Male & Female \\
\hline 1. Condition & 64 & 60 & - & - & - & - & - & - \\
2. Intrasexual competition & 64 & 59 & 2.98 & 2.91 & 0.99 & 0.99 & 4.75 & 3.92 \\
3. Jealousy & 64 & 60 & 2.84 & 3.18 & 1.02 & 0.90 & 3.71 & 4.00 \\
4. Indirect aggression & 64 & 60 & 1.78 & 2.06 & 0.79 & 1.07 & 3.33 & 4.00 \\
5. Direct aggression & 64 & 60 & 1.68 & 1.21 & 0.96 & 0.50 & 3.67 & 2.33 \\
\hline
\end{tabular}




\section{RESULTS}

\section{Multivariate main effects}

A two-way between-subjects multivariate analysis of variance (MANOVA) was conducted on four dependent variables: intrasexual competitive attitude, jealousy, indirect aggression toward a sexual competitor and direct aggression toward a sexual competitor. Independent variables were the mate availability priming condition, gender and dating status. Results revealed a statistically significant multivariate main effect for condition (scarcity versus abundance), Wilks' $\lambda=.79, F(3,114)=$ $10.01, p<.001, \eta_{\mathrm{p}}{ }^{2}=.21$, indicating that $21 \%$ variance of the dependent variables was associated with the experimental condition. Results also showed a statistically significant main effect for gender, Wilks' $\lambda=.80, F(3,114)=9.60, p<.001, \eta_{\mathrm{p}}{ }^{2}=$ .20 , indicating that $20 \%$ variance of the dependent variables was associated with participant gender. No main effects were observed for dating status, or for any of the two-way or three-way interactions.

\section{Intrasexually competitive attitude}

Given the significance of the overall test, the between-subject effects were examined. First, the effect of condition (mate scarcity versus abundance) on intrasexually competitive attitude was examined. Results indicated that jealous reaction toward a rival was significantly affected by the priming condition $F(1,116)=6.71, p<.01$, $\eta_{\mathrm{p}}{ }^{2}=.07$. Specifically, individuals in the mate scarcity condition were significantly more intrasexually competitive $(M=3.50, S D=0.84)$ than individuals in the mate abundance condition $(M=2.90, S D=1.13)$. There were no statistically significant effects for gender, dating status, or any two-way or three-way interactions.

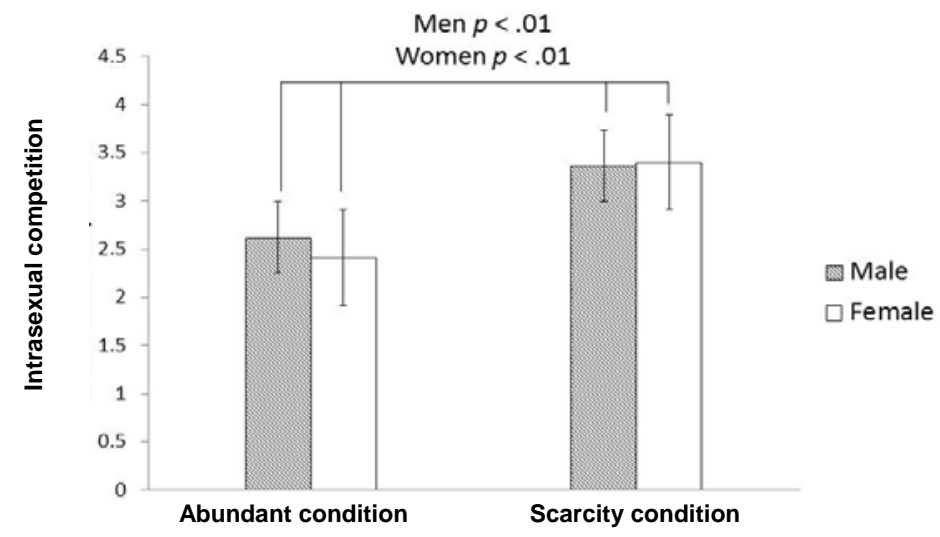

Figure 1. Mean scores for intrasexual competition in the mate abundant and mate scarcity conditions for males and females 


\section{Jealousy over rival interaction with mate}

Given the significance of the overall test, the between-subject effects were examined. First, the effect of condition (mate scarcity versus abundance) on jealousy toward an attractive rival who is attempting to mate with one's romantic partner was examined. Results indicated that jealous reaction toward a rival was significantly affected by the priming condition $F(1,116)=17.44, p<.001, \eta_{\mathrm{p}}{ }^{2}=.13$. Specifically, individuals in the mate scarcity condition were significantly more jealous ( $M$ $=3.40, S D=0.13)$ than individuals in the mate abundance condition $(M=2.65, S D$ $=.12$ ). There were no statistically significant effects for gender, dating status, or any two-way or three-way interactions.

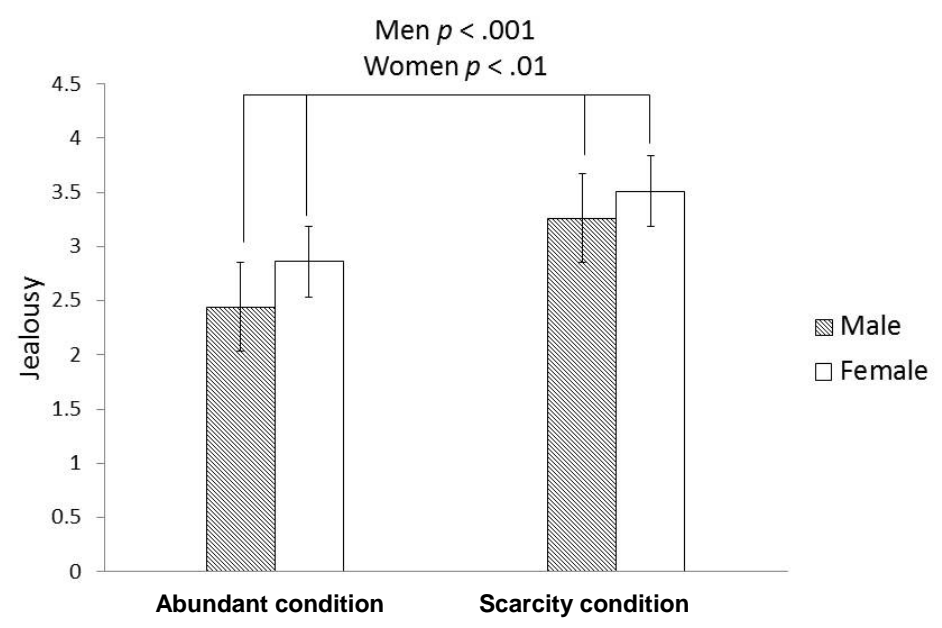

Figure 2. Mean scores for jealousy in the mate abundance and mate scarcity conditions for males and females

\section{Willingness to aggress indirectly against a rival}

Second, we examined potential differences in participants' willingness to aggress indirectly against an attractive sexual rival. Results showed that the use of indirect aggression toward an intrasexual competitor was significantly affected by the priming condition, $F(1,116)=28.75, p<.01, \eta_{\mathrm{p}}{ }^{2}=.20$, indicating that $20 \%$ of explained variance in indirectly aggressive tendency was attributable to the priming condition. Specifically, individuals exposed to the mate scarcity condition were significantly more likely to be willing to use indirect aggression $(M=2.37, S D=0.12)$ compared to those in the mate abundance condition $(M=1.49, S D=0.11)$. Again, neither gender nor any of the interactions produced further statistically significant effects. 


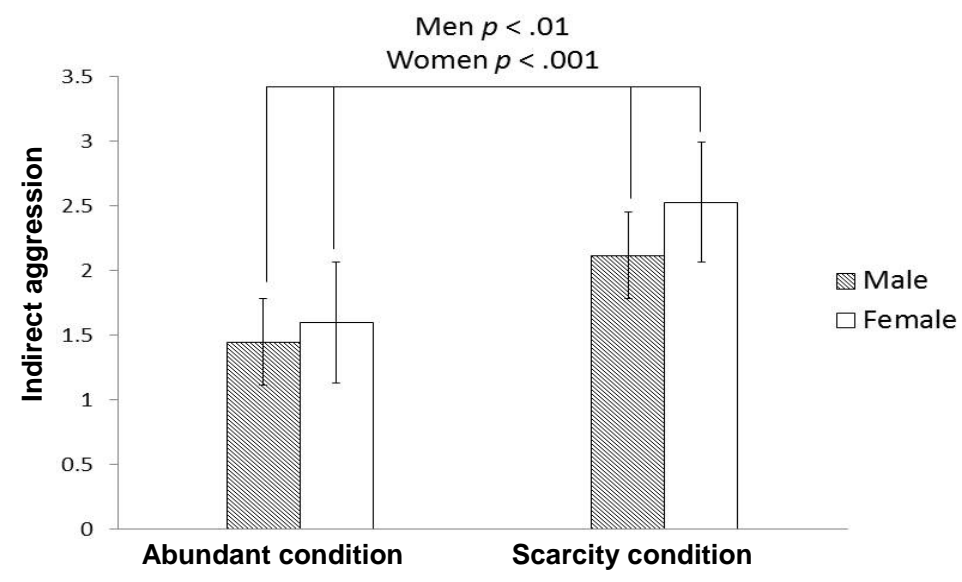

Figure 3. Mean scores for indirect aggression in the mate abundance and mate scarcity conditions for males and females

\section{Willingness to aggress physically against a rival}

Third, we explored potential differences in participants' willingness to aggress physically against an attractive sexual rival. Results found that individuals exposed to the mate scarcity condition were more likely to use physical aggression $(M=$ $1.63, S D=0.10)$ compared to those in the mate abundance condition $(M=1.27, S D$ $=0.09$ ). However, after applying our Bonferroni-corrected $p$-value, this finding did

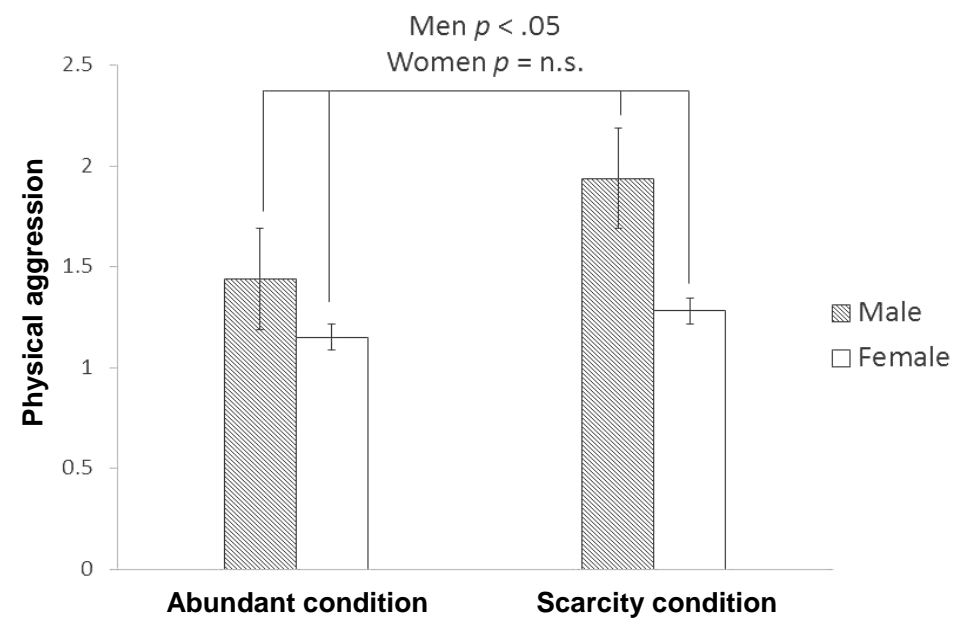

Figure 4. Mean scores for physical aggression in the mate abundance and mate scarcity conditions for males and females. Note that given the Bonferroni-corrected $p$-value employed in the current study, the threshold of $p<.05$ for males is interpreted as being non-significant 
not reach the threshold for statistical significance, $F(1,116)=5.82, p<.05, \eta_{\mathrm{p}}{ }^{2}=$ .05 . The model accounted for $5 \%$ of explained variance in physically aggressive tendency. There was, however, a statistically significant difference in physical aggression based upon gender, $F(1,116)=12.56, p<.01, \eta_{\mathrm{p}}^{2}=.10$, which accounted for $10 \%$ of additional explained variance. Specifically, men $(M=1.72$, $S D=0.09)$ compared to women $(M=1.10, S D=0.09)$ were statistically significantly more likely to use physical aggression against a rival.

\section{DISCUSSION}

In many sexually reproducing species, mate scarcity can lead to more variability in mating access and to corresponding increases in intrasexual competition and mateguarding behavior (WEIR, GRANT and HUTCHINGS 2011). The current study examined whether this evolutionary principle applies to human behavior. Participants were primed with the belief that mates were either scarcely or abundantly available. We hypothesized that participants in the mate scarcity condition compared to the mate abundance condition would exhibit 1) a more competitive attitude toward members of the same sex, 2) more jealousy, and 3) more willingness to aggress indirectly against a hypothetical same-sex rival who was vying for their mate.

Results of the present study supported the hypothesis that perceived mate scarcity increases intrasexual competition in humans. First, both men and women in the mate scarcity condition reported stronger intrasexually competitive attitudes compared to individuals in the mate abundance condition (Hypothesis 1). Specifically, individuals in the mate scarcity condition more strongly endorsed items such as an expressed desire to look for negative characteristics in attractive rivals, wanting to beat rivals, wanting to be perceived as funnier and more attractive than rivals, willingness to reject hiring an attractive rival, and more distress over the social standing and possessions of rivals (e.g., having a nicer house). This suggests a broad attitudinal shift toward intrasexual competitiveness among those who perceived mates to be scarce. However, intrasexual competition consists of more than a mere attitude or disposition. Given this broad attitudinal shift, we further examined group differences in both emotional and behavioral responses to a hypothetically contested romantic relationship. We were specifically interested in responses that indicated intrasexual competition toward a rival who was attempting to mate-poach.

Intrasexual competition often involves actions taken to facilitate the acquisition or retention of desired mating relationships (BUSS 1988). Participants were exposed to a hypothetical scenario in which a high mate value intrasexual rival was flirting with the participant's mate at a party. Under conditions of perceived mate scarcity, a man or woman might perceive this rival as being more motivated to poach their partner due to relative mate scarcity. Simultaneously, they might perceive their partner as having more selective power or opportunity to upgrade to a higher quality mate; either of these thought processes could then instigate emotions 
and behaviors relevant to mate retention. Results showed that participants in the mate scarcity condition were significantly more jealous of the rival compared to individuals in the mate abundance condition (Hypothesis 2). Although previous research has suggested that the ultimate sources of jealousy differ between the sexes (e.g., importance of sexual versus emotional infidelities; Harris, 2003), it is nevertheless clear that both men and women experience jealousy when threatened with a partner's infidelity (ARNOCKY et al. 2012; HARRIS 2003; HASELTON and GANGESTAD 2006). Given that romantic jealousy may have evolved as a response to threats to a desired relationship (BUSS and HASELTON 2005), it is not surprising that this emotion would be heightened under conditions of mate scarcity. In these circumstances, jealousy might then function as a signal of the need for compensatory mate retention behaviors (e.g., MANER et al. 2005) perhaps including direct and/or indirect aggression (ARNOCKY et al. 2012; BUSS 1988, 1994; DALY WILSON and WEGHORST 1982; SYMONS 1979).

Results indicated that mate availability also influenced participants' willingness to aggress against the rival. For men, the relationship between mate scarcity and direct aggression was statistically non-significant after applying the Bonferroni correction. Conversely, men in the mate scarcity condition were significantly more likely than men in the mate abundance condition to aggress indirectly against the rival. Although men have been known to be more physically aggressive than women, our results are consistent with literature suggesting males gradually decrease their use of physical aggression tactics through adolescence and increase indirectly aggressive strategies (BJORKQVIST, OSTERMAN and LAGERSPETZ 1994). Results from the current study support recent data obtained from hunter-gatherer societies which suggest that intrasexual competition rarely consists of physical combat, as evidenced by the fact that "humans have a much lower degree of body mass sexual dimorphism than is predicted by our OSR" (MARLOWE and BARBESQUE 2012).

Similar to men, we found that women in the mate scarcity condition were significantly more likely than women in the mate abundance condition to aggress indirectly against a rival. Although some females do utilize physical aggression (BUUNK and FISHER 2009), previous research has illustrated that females rely primarily upon indirectly aggressive tactics (e.g. BJORKQVIST 1994; VAILLANCOURT et al. 2010). Social relationships are particularly important to women (ROSE and RUDOLPH 2006). Interfering with competitors' social ties by using indirect aggression such as gossiping and exclusionary tactics may be an effective intrasexual competition strategy, as it can detract from a rival's status, mental health and physical health and can simultaneously bolster one's own desirability to the opposite sex (ARNOCKY et al. 2012; ARNOCKY and VAILLANCOURT 2012; CAMPBELL 1998, 2005; Fisher and COX 2009; VAILLANCOURT 2005; VAILlANCOURT et al. 2010). Given that indirect aggression seems to be a useful strategy for intrasexual competition, it is not surprising that we found participants' willingness to use aggression would increase under conditions of perceived mate scarcity. 
Taken together, these findings suggest that similar to other species, humans have a tendency toward intrasexual competition under conditions of mate scarcity compared to conditions of mate abundance. These findings may also shed light on why intrasexual competition persists even in regions, communities and subcultures with nearly equitable sex ratios. The perception of mate availability need not be grounded in objective environmental pressures. Things of value are often perceived as being scarce (i.e., the value heuristic). DAI, WERTENBROCH and BRENDL (2008) exposed participants to a set of pictures consisting equally of photos of birds and of flowers. The researchers offered to pay participants for either every bird picture or every flower picture that they observed. Although an equal number of bird and flower pictures were shown, participants rated the value-linked images as being scarcer than the images which they were not being paid to observe. The authors then extended this concept to human mating by exposing participants to portraits of same-sex and opposite-sex individuals. When the portraits of opposite-sex individuals were attractive (and thus valuable), these images were rated as occurring less frequently. This effect was not observed when the opposite-sex individuals were unattractive. If humans have implicit cognitive mechanisms for perceiving things of value as being scarce, then the results of the present study suggest that the mere perception of mate scarcity will produce sexually competitive behavior regardless of the accuracy of that perception.

\section{Limitations and future directions}

This study was limited by its focus on a narrow age group of 17- to 30-year-old participants. However, we focused on this age range given that individuals are at their reproductive peak (SHACKELFORD, POUND and GOETZ 2005) and contend for mates most often within the aforementioned age range (BUSS 1998; SHACKELFORD et al. 2005).

The current study employed an aggression scenario that was hypothetical. Attitudes toward aggression are known to correlate with self-reports of actual aggressive behavior (e.g., ANDERSON et al. 2006; Wells, TrEMBlay and GRAHAM 2013). Further research might utilize an in-vivo aggressive task to test participants' aggressive reactions toward rivals. For example, previous research has explored participants' willingness to assign a spectrum of aversive or appetitive tastes to another participant who had either given them positive or negative feedback on an essay (JENSEN-CAMPBELL et al. 2007). The anonymous assignment of aversive or appetitive tastes to real or imagined sexual competitors might provide an interesting avenue for observing actual indirectly aggressive responses to rivals across mate availability conditions.

Subsequent research might also explore the effects of mate abundance versus scarcity on participants' self-perceived mate value, as well as their willingness to adopt risky mating strategies, such as mate-poaching. If an individual perceives 
members of the opposite sex as being scarce, self-reported mate value may decrease and a willingness to attempt a mate-poach might increase. When one believes their own sex to be a scarce resource, advantages such as adopting one's preferential mating strategies as well as being increasingly selective in mate choice would be expected (see also WATKINS et al. 2012). Cross-sectional research has found broad correlations between OSR and mating systems, such that male abundance relates to increased monogamy and female abundance to increased casual sex (e.g., KRUGER, FITZGERALD and PETERSON 2011; KRUGER and SCHLEMMER 2009). It would be of interest to determine whether individual differences in desired relational commitment and sociosexuality fluctuate based on experimental manipulation of perceived mate availability.

\section{CONCLUSIONS}

Mate scarcity and its effects on sexual competition have been observed within a variety of non-human animals (COLWELL and ORING 1988; JIROTKUL 1999; MITANI et al. 1996). However, little empirical research has addressed similar contexts among humans. Real or perceived mate scarcity may be particularly important to human behavior given biases in value heuristics which assign greater worth to perceivably scarce objects, including mates. We found that individuals who were primed to believe they have a limited amount of selection in opportunities for mating were more intrasexually competitive, jealous and aggressive toward potential rivals compared to individuals primed to believe mates were abundant. This study highlights our similarity to other sexually reproducing species, in that human intrasexual conflict has likely evolved as a contextually sensitive and adaptive response to changes in the availability of mates.

\section{Note}

${ }^{1}$ The wording of this narrative scenario is sex-reversed for female participants. This measure has been used in previous samples consisting of individuals who are either romantically attached or unattached.

\section{REFERENCES}

Anderson, C. A., Benjamin, A. J., Wood, P. K. and Bonacci, A. M. (2006): Development and testing of the Velicer Attitudes toward Violence Scale: Evidence for a four-factor model. Aggressive Behavior, 32, 122-136.

ARCHER, J. (1994): Testosterone and aggression. Journal of Offender Rehabilitation, 21(3-4), 3-39. doi:10.1300/J076v21n03_02

ARCHER, J. (2000): Sex differences in aggression between heterosexual partners: A meta-analytic review. Psychological Bulletin, 126(5), 651-680. doi:10.137/00332909.126.5.651 
ARCHER, J. (2004): Sex differences in aggression in real-world settings: A meta-analytic review. Review of General Psychology, 8(4), 291-322. doi:10.1037/1089-2680.8.4.291

ARCHER, J. and CôTÉ, S. (2005): Sex differences in aggressive behavior: A developmental and evolutionary perspective. In: R.E. Tremblay, W.W. Hartup and J. Archer (eds), Developmental Origins of Aggression. New York: Guilford Press, pp. 83-106.

ARNOCKY, S., SUNDERANI, S. and VAILlANCOURT, T. (2013): Mate poaching and mating success in humans. Journal of Evolutionary Psychology, 11(2), 65-83. doi: 10.1556/ JEP.11.2013.2.2

Arnocky, S., Sunderani, S., Miller, J. and Vaillancourt, T. (2012): Jealousy mediates the relationship between attractiveness comparison and females' indirect aggression. Personal Relationships, 19(2), 290-303. doi:10.1111/j.1475-6811.2011.01362.x

ARnOCKY, S. and VAillancourt, T. (2012): A multi-informant longitudinal study on the relationship between aggression, peer victimization, and dating status in adolescence. Evolutionary Psychology, 10(2), 253-270.

Aronsen, T., Mobley, K. B., Berglund, A., Sundin, J., Billing, A. M. and Rosenqvist, G. (2013): The operational sex ratio and density influence spatial relationships between breeding pipefish. Behavioral Ecology, 24(3). doi:10.1093/beheco/art019

BARBER, N. (2009): Countries with fewer males have more violent crime: Marriage markets and mating aggression. Aggressive Behavior, 35, 49-56. doi: 10.1002/ab.20291

BARBER, N. (1999): Women's dress fashions as a function of reproductive strategy. Sex Roles, 40(5-6), 459-471. doi:10.1023/A:1018823727012

BAteman, A. J. (1948): Intra-sexual selection in drosophila. Heredity, 2, 349-368. doi:10.1038/ hdy. 1948.21

Benenson, J. F., Markovits, H., Thompson, M. E. and Wrangham, R. W. (2011): Under threat of social exclusion, females exclude more than males. Psychological Science, 22(4), 538544. doi:10.1177/0956797611402511

Berglund, A. (1994): The operational sex ratio influences choosiness in a pipefish. Behavioral Ecology, 5(3), 254-258. doi:10.1093/beheco/5.3.254

BJORKQVIST, K. (1994): Sex differences in physical, verbal, and indirect aggression: A review of recent research. Sex Roles, 30(3), 177-188. doi:10.1007/BF01420988

BJorkQvist, K., OSTERMAN, K. and LAGERSPETZ, K. J. (1994): Sex differences in covert aggression among adults. Aggressive Behavior, 20, 27-33.

Buss, D.M. (1988): The evolution of human intrasexual competition: Tactics of mate attraction. Journal of Personality and Social Psychology, 54(4), 616-628. doi:10.1037//00223514.54.4.616

Buss, D.M. (1994): The strategies of human mating. American Scientist, 82(3), 238-249.

Buss, D.M. (1998): Sexual strategies theory: Historical origins and current status. Journal of Sex Research, 35, 19-31. doi:10.1080/00224499809551914

Buss, D.M. (2008): Attractive women want it all: Good genes, economic investment, parenting proclivities, and emotional commitment. Evolutionary Psychology, 6(1), 134-146.

Buss, D. M. and DeDDEN, L. (1990): Derogation of competitors. Journal of Social and Personal Relationships, 7(3), 395-422. doi:10.1177/0265407590073006

Buss, D.M. and SHACKELFORD, T. (1997): Human aggression in evolutionary psychological perspective, 17(6), 605-619. doi:10.1016/S0272-7358(97)00037-8

Buss, D. M. and Haselton, M. G. (2005): The evolution of jealousy. Trends in Cognitive Science, 9(11), 506-507. doi:10.1016/j.tics.2005.09.006

BuUnK, A. and FisHER, M. (2009): Individual differences in intrasexual competition. Journal of Evolutionary Psychology, 7, 37-48. doi:10.1556/JEP.7.2009.1.5

CAMPBELl, A. (1995): A few good men: Evolutionary psychology and female adolescent aggression. Ethology and Sociobiology, 16(2), 99-123. doi:10.1016/0162-3095(94)00072-F 
CAMPBELl, A. (1999): Staying alive: Evolution, culture, and women's intrasexual aggression. Behavioral and Brain Sciences, 22(2), 203-252. doi:10.1017/S0140525X99001818

CAmpBell, A. (2004): Female competition: Causes, constraints, content and contexts. Journal of Sex Research, 41, 6-26. doi:10.1080/00224490409552210

Clutton-Brock, T. (2007): Sexual selection in males and females. Science, 318(5858), 1882 1885. doi:10.1126/science.1133311

Colwell, M. and ORING, L. (1988): Sex ratios and intrasexual competition for mates in a sexrole reversed shorebird, Wilson's Phalarope (Phalaropus tricolor). Behavioral Ecology and Sociobiology, 22(3) 165-173. doi:10.1007/BF00300566

COX, A. and FisHER, M. (2008): A framework for exploring intrasexual competition. The Journal of Social, Evolutionary, and Cultural Psychology, 2(4), 144-155.

Dai, X., Wertenbroch, K. and BrendL, C. M. (2008): The value heuristic in judgments of relative frequency. Psychological Science, 19, 18-19. doi:10.1111/j.1467-9280.2008.02039.x

DALY, M. and Wilson, M. (1988): Homicide. New York: Aldine.

DALY, M. and WiLSON, M. (1989): Homicide and cultural evolution. Ethology and Sociobiology, 10(1-3), 99-110. doi:10.1016/0162-3095(89)90014-9

DAly, M., Wilson, M. and Weghorst, S.J. (1982): Male sexual jealousy. Ethology and Sociobiology, 3, 11-27. doi:10.1016/0162-3095(82)90027-9

DARWIN, C. (1859): On the origin of the species by means of natural selection, or the Preservation of favoured races in the struggle for life. London: John Murray.

DARWIN, C. (1871): The descent of man and selection in relation to sex. London: John Murray.

DE Jong, K. D., Forsgren, E., SAndviK, H., and Amundsen, T. (2012): Measuring mating competition correctly: available evidence supports operational sex ratio theory. Behavioral Ecology, 23(6), 1170-1177. doi: 10.1093/beheco/ars094

DiJKSTRA, P. and BUUNK, B. (1998): Jealousy as a function of rival characteristics: An evolutionary perspective. Personality and Social Psychology Bulletin, 24(11), 1158-1166. doi: $10.1177 / 01461672982411003$

DiJKstRA, P. and BuUnK, B. (2002): Sex differences in the jealousy-evoking effect of rival characteristics. European Journal of Social Psychology, 32(6), 829-852. doi:10.1002/ejsp.125

Durante, K. M., Griskevicius, V., Simpson, J. A., CAntú, S. M. and Tybur, J. M. (2012): Sex ratio and women's career choice: Does a scarcity of men lead women to choose briefcase over baby? Journal of Personality and Social Psychology, 103 (1), 121-134. doi: $10.1037 / \mathrm{a} 0027949$

EMLEN, S. and ORING, L. W. (1977): Ecology, sexual selection, and the evolution of mating systems. Science, 197(4300), 215-223. doi:10.1126/science.327542

FERNANDEZ-DUQUE and E. HUCK, M. (2013): Till death (or an intruder) do us part: Intrasexual competition in a monogamous primate. PLOS one, $8,1-5$.

FisheR, M. and Cox, A. (2009): The influence of female attractiveness on the effectiveness of competitor derogation. Journal of Evolutionary Psychology, 7(2), 141-155. doi:10.1556/ JEP.7.2009.2.3

FisheR, R. A. (1930): The Genetical Theory of Natural Selection. Clarendon Press: Oxford.।

FLINN, M. V. (1988): Mate guarding in a Caribbean village. Ethology and Sociobiology, 9(1), 128. doi: 10.1016/0162-3095(88)90002-7

GAngestad, S. W. and Simpson, J. A. (2000): The evolution of human mating: Trade-offs and strategic pluralism. Behavioral and Brain Sciences, 23(4), 573-644. doi:10.1017/ S0140525X0000337X

GEARY, D. C. (2000): Evolution and proximate expression of human paternal investment. Psychological Bulletin, 126, 55-77. doi:10.1037/0033-2909.126.1.55

Gould, S. J. (1974): Origin and function of 'bizarre' structures: Antler size and skull size in the 'Irish elk,' Megaloceros giganteus. Evolution, 28(2), 191-220. doi:10.2307/2407322 
Griskevicius, V., Tybur, J. M., Ackerman, J. M., Delton, A. W., Robertson, T. E. and White, A. E. (2011): The financial consequences of too many men: Sex ratio effects on saving, borrowing, and spending. Journal of Personality and Social Psychology, 102(1), 69-80. doi: 10.1037/a0024761

Griskevicius, V., Tybur, J. M., Gangestad, S. W., Perea, E. F., Shapiro, J. R. and Kenrick, D. T. (2009): Aggress to impress: Hostility as an evolved context-dependent strategy. Journal of Personality and Social Psychology, 96(5), 980-994. doi:10.1037/a0013907

HARRIS, C. R. (2003): A review of sex differences in sexual jealousy, including self-report data, psychophysiological responses, interpersonal violence, and morbid jealousy. Personality and Social Psychology Review, 7, 102-128.

Haselton, M. G. and GANGeStAD, S. W. (2006): Conditional expression of women's desires and men's mate guarding across the ovulatory cycle. Hormones and Behavior, 49(4), 509-518. doi:10.1016/j.yhbeh.2005.10.006

Jensen-Campbell, L. A., Knack, J. M., Waldrip, A. M and Campbell, S. D. (2007): Do big five personality traits associated with self-control influence the regulation of anger and aggression? Journal of Research in Personality, 41(2), 403-424. doi:10.1016/ j.jrp.2006.05.001

JiROTKUL, M. (1999): Operational sex ratio influences preference and male-male competition in guppies. Animal Behavior, 58(2), 287-294. doi:10.1006/anbe.1999.1149

Jones, B. C., Little, A. C., Penton-Voak, I. S., Tidderman, B. P., Burt, D. M. and Perrett, D. I. (2001): Facial symmetry and judgments of apparent health: Support for a 'good genes' explanation of the attractiveness-symmetry relationship. Evolution and Human Behavior, 22(6), 417-429. doi:10.1016/S1090-5138(01)00083-6

Kruger, D. J., Fitzgerald, C. J. and Peterson, T. (2010): Female scarcity reduces women's marital ages and increases variance in men's marital ages. Evolutionary Psychology, 8(3), $420-431$.

Kruger, D. J. and Schlemmer, E. (2009): Male scarcity is differentially related to male marital likelihood across the life course. Evolutionary Psychology, 7, 280-287.

LEE, J. H. and PARK, D. (2009): Effects of body size, operational sex ratio, and age on pairing by the Asian toad, Bufo stejnegeri. Zoological Studies, 48(3), 334-332.

Li, N. P., BAiley, J.M., Kenrick, D. T. and Linsenmeier, J. A. W. (2002): The necessities and luxuries of mate preferences: Testing the tradeoffs. Journal of Personality and Social Psychology, 82(6), 947-955. doi: 10.1037/0022-3514.82.6.947

LI, N. P. and KENRICK, D. T. (2006): Sex similarities and differences in preferences for short-term mates: What, whether, and why. Journal of Personality and Social Psychology, 90(3), 468489. doi:10.1037/0022-3514.90.3.468

Maner, J. K., Kenrick, D. T., Becker, V., Robertson, T. E., Hofer, B., Neuberg, S. L., et al. (2005): Functional projection: How fundamental social motives can bias interpersonal perception. Journal of Personality and Social Psychology, 88, 63-78. doi:10.1037/00223514.88.1.63

MARlowe, F. W. and BARBesQue, J. C. (2012): The human operational sex ratio: Effects of marriage, concealed ovulation, and menopause on mate competition. Journal of Human Evolution, 63, 834-832.

MAYNARD SMITH, J. (1974): The theory of games and the evolution of animal conflicts. Journal of Theoretical Biology, 47, 209-221. doi:10.1016/0022-5193(74)90110-6

MitANi, J. C., GRos-LouIS, J., RichARDS, A. F. (1996): Sexual dimorphism, the operational sex ratio, and the intensity of male competition in polygynous primates. The American Naturalist, 147(6), 966-980. Retrieved from http://www.jstor.org/stable/2463187

Pedersen, F. A. (1991): Secular trends in human sex ratios: Their influence on individual and family behavior. Human Nature, 2(3), 271-291. doi:10.1007/BF02692189 
Pollet, T. and Nettle, D. (2008): Driving a hard bargain: Sex ratio and male marriage success in a historical US population. Biology Letters, 4, 31-33. doi:10.1098/rsbl.2007.0543

Rose A .J. and RudolPh, K. D. (2006): A review of sex difference in peer relationship processes: Potential trade-offs for the emotional and behavioral development of girls and boys. Psychological Bulletin, 132, 98-131. doi:10.1037/0033-2909.132.1.98

SchmitT, D. P. (2005): Sociosexuality from Argentina to Zimbabwe: A 48-nation study of sex, culture, and strategies of human mating. Behavioral and Brain Sciences, 28, 247-311. doi: $10.1017 / \mathrm{S} 0140525 \mathrm{X} 05000051$

Shackelford, T., Pound, N. and Goetz, A. (2005): Psychological and physiological adaptations to sperm competition in humans. Review of General Psychology, 9(3) 228-248. doi: $10.1037 / 1089.2680 .9 .3 .228$

South, S. J. and Trent, K. (1988): Sex ratios and women's roles: A cross-national analysis. American Journal of Sociology, 93(5), 1096-1115. doi:10.1086/228865

Spielmann, S. S., MacDonald, G. and Wilson, A. E. (2009): On the rebound: Focusing on someone new helps anxiously attached individuals let go of ex-partners. Personality and Social Psychology Bulletin, 35(10), 1382-1394. doi:10.1177/0146167209341580

Stone, E. A, Shackelford, T. K. and Buss, D. M. (2007): Sex ratio and mate preferences: A cross-cultural investigation. European Journal of Social Psychology, 37(2), 288-296. doi:10.1002/ejsp.357

Sunderani, S., ARnocky, S. and Vaillancourt, T. (2013): Individual differences in mate poaching: An examination of hormonal, dispositional, and behavioral mate-value traits. Archives of Sexual Behavior, 42(4), 533-542. doi: 10.1007/s10508-012-9974-y

Symons, D. (1979): The Evolution of Human Sexuality. New York: Oxford University Press.

TAYLOR, L. D. (2013): Male partner selectivity, romantic confidence, and media depictions of partner scarcity. Evolutionary Psychology, 11(1), 36-49.

TEJedO, M. (1988): Fighting for females in the toad Bufo calamita is affected by the operational sex ratio. British Journal of Animal Behaviour, 36(6), 1765-1769. doi:10.1016/S00033472(88)80115-5

Thornhill, R. and GAngestad, S. W. (2006): Facial sexual dimorphism, developmental stability and susceptibility to disease in men and women. Evolution and Human Behavior, 27(2), 131-144. doi:10.1016/j.evolhumbehav.2005.06.001.

TRIVERS, R. (1972): Parental investment and sexual selection. In: B. Campbell (ed.), Sexual Selection and the Descent of Man 1871-1971. Chicago, IL: Aldine, pp. 180-230.

VAILLANCOURT, T. (2005): Indirect aggression among humans: Social construct or evolutionary adaptation? In: R.E. Tremblay, W.H. Hartup and J. Archer (eds), Developmental Origins of Aggression. NY: Guilford Press, pp. 158-177.

Vaillancourt, T., Miller, J. and Sharma, A. (2010): “Tripping the Prom Queen": Female intrasexual competition and indirect aggression. In: K. Osterman (ed.), Indirect and Direct Aggression. Frankfurt, Germany: Peter Lang Publishing, pp. 17-32.

Wacker, S., Mobley, K., Forsgren, E., Cats Myhre, L., de Jong, K. and Amundsen, A. (2013): Operational sex ratio but not density affects sexual selection in fish. Evolution, 67(7), 1937-1949. doi:10.1111/evo.12092

WALters, S. and CRAWFORD, C. B. (1994): The importance of mate attraction for intrasexual competition in men and women. Ethology and Sociobiology, 15, 5-30. doi:10.1016/01623095(94)90025-6

Watkins, C. D., Jones, B. C., Little, A. C., DeBruine, L. and Feinberg, D. R. (2012): Cues to the sex ratio of the local population influence women's preferences for facial symmetry. Animal Behaviour, 83(2), 545-533. doi:10.1016/j.anbehav.2011.12.002 
WeIR, L. K., Grant, J. W. A. and Hutchings, J. A. (2011): The influence of operational sex ratio on the intensity of competition for mates. The American Naturalist, 177(2), 167-176. doi:10.1086/657918

Wells, Tremblay and Graham (2013): Understanding men's aggression in bars: Development of the Beliefs and Attitudes toward Male Alcohol-Related Aggression (BAMARA) Inventory. Alcoholism: Clinical and Experimental Research, 37(S1), E260-E270. doi: $10.1111 /$ j.1530-0277.2012.01912.x

WILSON, M. and DALY, M. (1985): Competitiveness, risk taking, and violence: The young male syndrome. Ethology and Sociobiology, 6, 59-73. doi:10.1016/0162-3095(85)90041-X

ZHANG, J. and ZHANG, Z. (2003): Influence of operational sex ratio and density on the copulatory behavior and mating system of Brandt's vole Microtus brandti. Acta Theriologica, 48(3), 335-346. doi:10.1007/BF03194173 